\title{
THE MOSS GENUS AULACOPILUM (ERPODIACEAE, BRYOPHYTA) NEW TO THE EASTERN GHATS IN PENINSULAR INDIA
}

\author{
P. M. Biju, V. Asha and A. E. D. Daniels* \\ Bryology Laboratory, Department of Botany and Research Centre, Scott Christian College, \\ Nagercoil-629 003, Tamil Nadu, India; *E-mail: dulipdaniels@yahoo.co.uk
}

(Received 13 October, 2016; Accepted 25 January, 2017)

Aulacopilum beccarii, earlier known from the Western Ghats for India is added here to the moss flora of the Eastern Ghats. This record is just the second for Asia and India as well, and on the other hand, the genus is new to the Eastern Ghats. A brief description with figures and a photographic plate are provided.

Key words: Aulacopilum beccarii, Eastern Ghats, Western Ghats

\section{INTRODUCTION}

Aulacopilum Wilson with 8 species world-wide, belongs to the family Erpodiaceae. Of these, A. beccarii (Müll. Hal. ex Venturi) Mitt. and A. glaucum Wilson were reported as new to Asia and India, respectively by Daniels et al. (2012) from the Western Ghats in Peninsular India.

Surveys made on the Eastern Ghats in Peninsular India recently, led to the discovery of $A$. beccarii, which is just the second record for Asia and India as well, and from a different phytogeographical region. Incidentally, the genus is new to the Eastern Ghats. A brief description is provided supported by figures and a photographic plate. The specimen is housed at SCCN.

\section{Aulacopilum beccarii (Müll. Hal. ex Venturi) Mitt.}

(Figs 1-34)

Basionym: Erpodium beccarii Müll. Hal. ex Venturi, Nuovo Giorn. Bot. Ital. 4 : 18 (1872). $\equiv$ Aulacopilum beccarii (Müll. Hal. ex Venturi) Mitt., J. Linn. Soc., Bot. 13: 308 (1873); Brotherus in Engler and Prantl, Nat. Pflanzenfam. ed. 2, 2(11): 3 (1925); Crum, H. A., Beih. Nova Hedwigia 23: 211 (1972); Pursell, Mem. New York Bot. Gard. 69: 586 (1994); Hodgetts, J. Bryol. 19: 116 (1996); Stone, J. Bryol. 19: 494 (1997); Magill and van Rooy in Leistner, Fl. S. Africa: 453 (1998); Pursell and Allen, Monogr. Syst. Bot. Missouri Bot. Gard. 90: 524 (2002). - Type: Africa, Ethiopia, Beccari, s.n. (NY).

= Erpodium paraguense Besch., Mém. Soc. Sci. Nat. Math. Cherbourg 21: 265 (1877). - Type: South America, Paraguay, on tree trunks, May 1877, Balansa 1214 (FH). 
= Erpodium lorentzianum Müll. Hal., Linnaea 42: 384 (1879). - Type: South America, Argentina, Mt Crún, 15 Sept. 1873, epiphytic on urundey?, Lorentz, s.n. (B, STR).

= Erpodium hanningtonii Mitt., J. Linn. Soc., Bot. 22: 313 (1886). - Type: Africa (SW. Kenya), Nyanza Prov., Lake Nyanza, on Adansonia digitata, Hannington, s.n. Herb. Mitt. (NY).

= Erpodium joannis-meyeri Müll. Hal., Flora 73: 486 (1890). - Type: Africa (NE Tanzania), Mt Kilimanjaro, 1,800 m, on a tree trunk, 1889, Hans Meyer, s.n. (B).

= Erpodium menyharthii Müll. Hal., Verh. k.-k. zool.-bot. Ges., Wien 43: 13 (1893). - Type: Africa, Zambezi, around Boroma (Somalia), on bark of tree trunk, Aug. 1890, Menyharth, s.n. (B).

=Erpodium opuntiae Cardot, Rev. Bryol. 37: 6 (1910). - Type: North America, Mexico, around Oaxaca, on Opuntia sp., 1894, Pringle 31a (FH, MICH, MO, NY).

Plants 1-1.5 cm long, slender, in loose or dense mats, dark green. Stems creeping, irregularly branched, green to brown, $c a 0.16 \times 0.12 \mathrm{~mm}$ in cross section, 11-12-celled across; cortex 2-layered; cells 4-12 × 3-8 $\mu \mathrm{m}$, thick-walled; medullary cells 10-24 × 8-20 $\mu \mathrm{m}$, thin-walled; branches horizontal to ascending. Leaves patent, deeply concave, 1-1.2 $\times 0.3-0.4 \mathrm{~mm}$, oblong-ovate, crenulate-papillose at margin, acute to acuminate, tapering to a uniseriate, brittle awn, ecostate; awn broad at base, ca $0.45 \mathrm{~mm}$ long, distantly serrulate; cells thin-walled, hexagonal to quadrate, multipapillate, distinct; papillae 2-5 per cell, verrucose; apical cells 12-20 × 8-16 $\mu \mathrm{m}$; median ones 12-16 × 10-14 $\mu \mathrm{m}$; those at base 10-28 $\times$ 8-20 $\mu \mathrm{m}$. Rhizoids clustered along ventral surface of stem, pale brown. Sporophytes on branches. Perichaetial leaves larger than vegetative ones, 2-2.6 (including awn) $\times 0.6-0.8 \mathrm{~mm}$, ovate-oblong, entire, acuminate; cells elongate-rhomboid; apical ones 32-64 × 8-10 $\mu \mathrm{m}$, epapillate; median ones 24-72 × 8-12 $\mu \mathrm{m}$, multipapillate; those at base 16-24 $\times 8-20 \mu \mathrm{m}$, epapillate. Setae ca $0.25 \mathrm{~mm}$ high. Capsules immersed, ca $1.2 \times 0.5 \mathrm{~mm}$, cylindric-ovoid, pale brown; annulus deeply inserted, with 5 or 6 rows of more or less rectangular, 16-32 × 8-12 $\mu \mathrm{m}$ cells. Operculum convex, rostellate, ca $0.35 \times 0.28 \mathrm{~mm}$. Stomata at capsule base only, ca $6 \times 4 \mu \mathrm{m}$; guard cells ca $20 \times 12 \mu \mathrm{m}$. Calyptra not seen. Spores globose to ovoid, 28-36 × 24-32 $\mu \mathrm{m}$, papillose, pale brown.

Habitat: Corticolous on Mangifera indica L. (Anacardiaceae), in mixed plantations, $c a 1,020 \mathrm{~m}$.

Distribution: Africa, Australia, Mexico, South America and India: Western Ghats and Eastern Ghats of Tamil Nadu.

Specimen examined: India, Tamil Nadu, Salem Dist., Eastern Ghats, Sherveroy Hills, Kottaikkad. Alt.: ca 1,020 m a.s.l., 12.08.2015, Daniels, A. E. D. and Biju, P. M. (11418 p.p.).

\section{DISCUSSION}

Based on the distributional records, Aulacopilum beccarii appears to be a tropical species. In the Western Ghats, the plant was found to grow on Albizia odoratissima (L.f.) Benth. (Mimosaceae), a medium-sized tree in degraded 


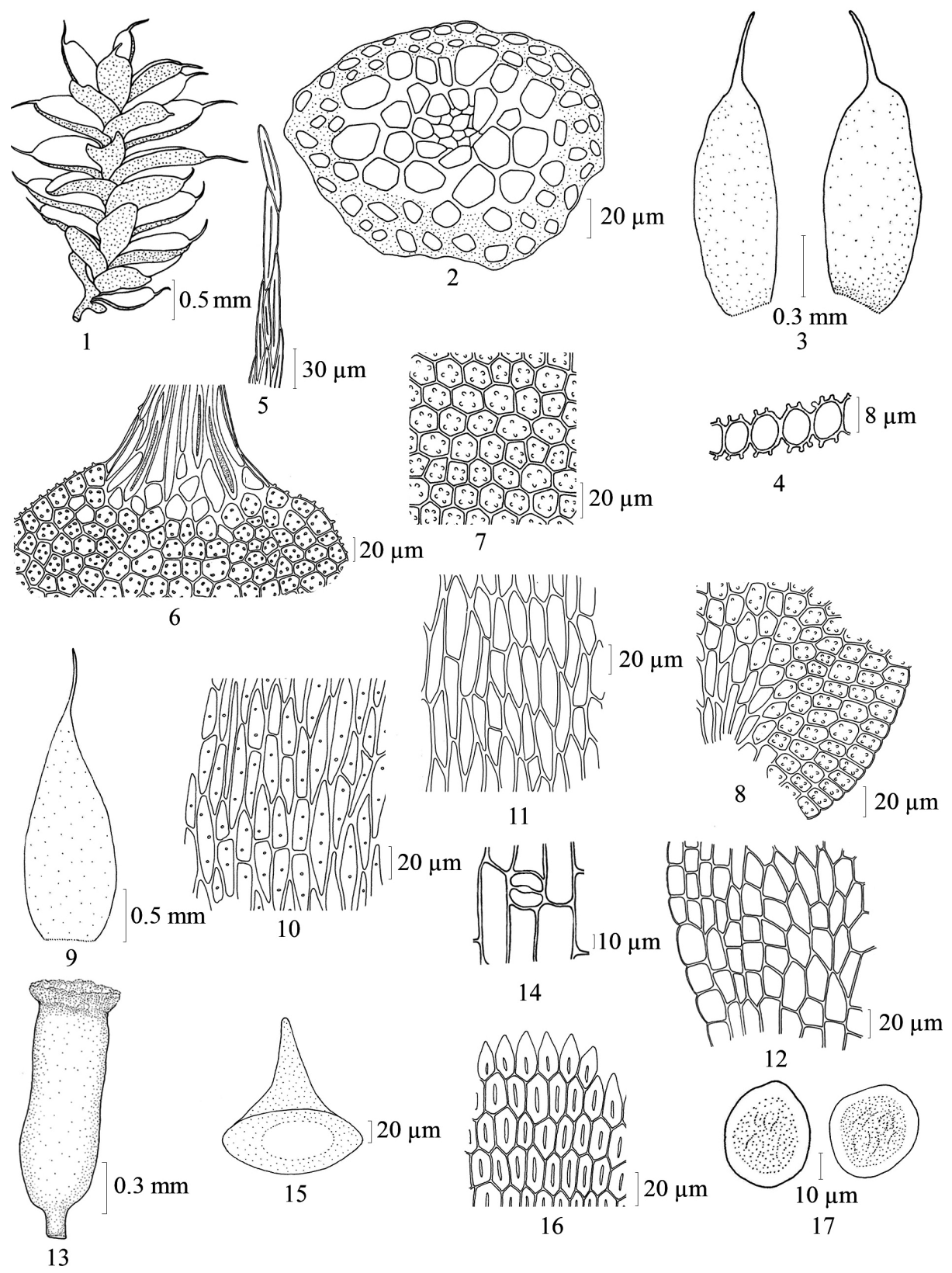

Figs 1-17. Aulacopilum beccarii (Müll. Hal.) Mitt. $-1=$ portion of plant, $2=$ cross section of stem, $3=$ leaves, $4=$ portion of cross section of leaf, $5=$ awn, $6=$ leaf apical cells, $7=$ leaf median cells, $8=$ leaf basal cells, $9=$ perichaetial leaf, $10=$ median cells of perichaetial leaf, $11=$ midbasal cells of perichaetial leaf, $12=$ basal cells of perichaetial leaf, $13=$ capsule, $14=$ stoma, 15 = operculum, 16 = annulus, 17 = spores (Daniels, A. E. D. and Biju, P. M. 11418 p.p.) 

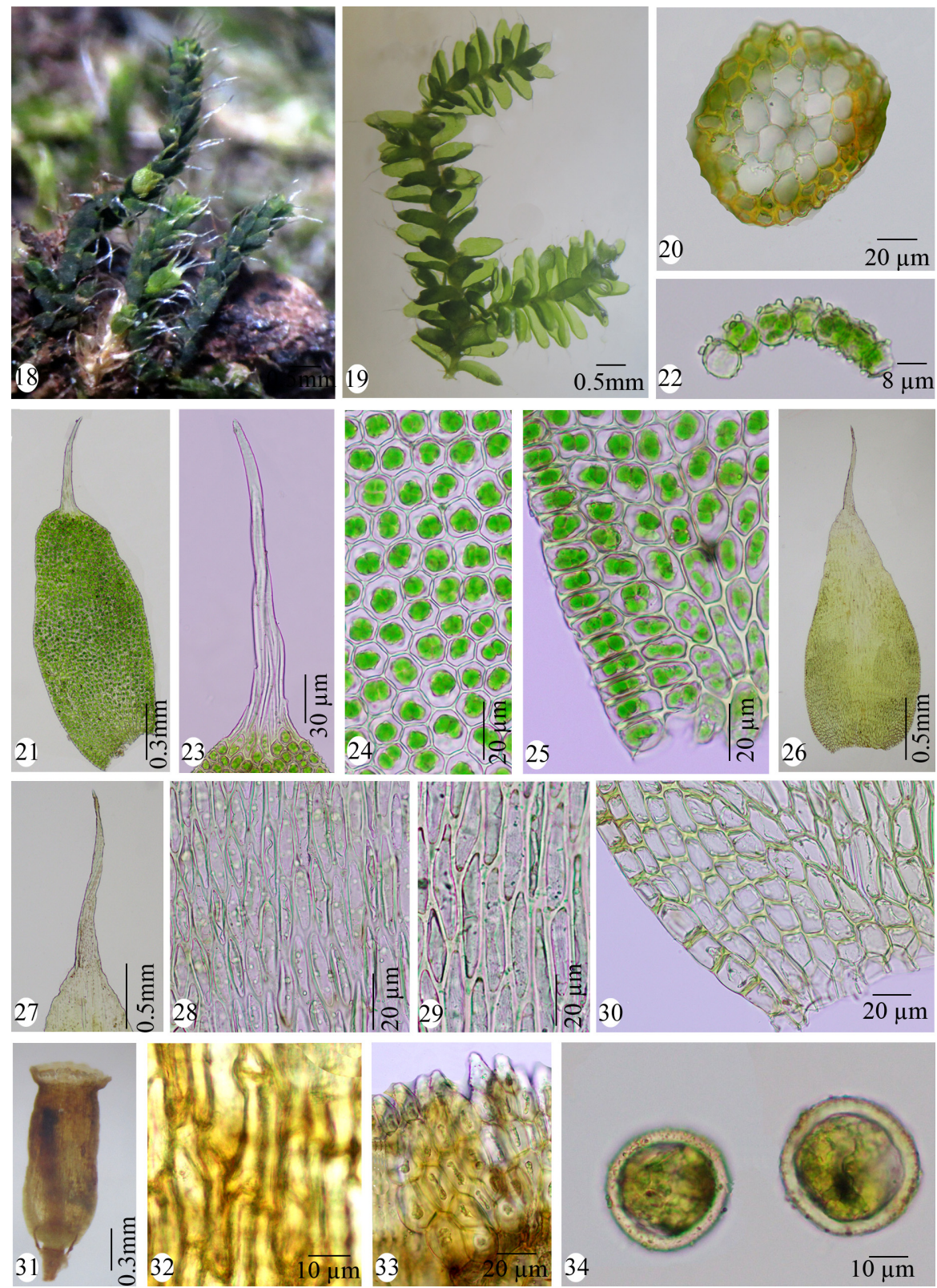

Figs 18-34. Aulacopilum beccarii (Müll. Hall.) Mitt. $-18=$ habitat, $19=$ plant, $20=$ cross section of stem, 21 = leaf, 22 = portion of cross section of leaf, $23=$ leaf apical cells, $24=$ leaf median cells, 25 = leaf basal cells, 26 = perichaetial leaf, 27 = apical cells of perichaetial leaf, $28=$ median cells of perichaetial leaf, $29=$ midbasal cells of perichaetial leaf, $30=$ basal cells perichaetial leaf, $31=$ capsule, $32=$ stomata, $33=$ annulus, $34=$ spores (Daniels, A. E. D. and Biju, P. M. 11418 p.p.) 
evergreen forests, ca $800 \mathrm{~m}$. In Kenya (Africa) it was corticolous on Adansonia digitata L. (Bombacaceae), whereas in Tanzania (Africa) it occurs on many kinds of native or planted trees and even on dry granitic rocks (Bizot and Pócs 1974). In Mexico (North America) it was epiphytic on Opuntia sp. (Cactaceae). The present collection was made on Mangifera indica L. in mixed plantations. This reveals that the species is neither host nor habitat specific.

Acknowledgements - We thank the Tamil Nadu State Forest Department for permission to explore the study area and help in the field. AEDD thanks the Ministry of Environment \& Forests and Climate Change, New Delhi, for financial assistance, and the Principal, Scott Christian College, for facilities.

\section{REFERENCES}

Bizot, M. and Pócs, T. (1974): East African bryophytes I. - Acta Acad. Paed. Agriensis n. ser. 12: 383-449.

Brotherus, V. F. (1925): Erpodiaceae. - In: Engler, H. G. A. and Prantl, K. A. E. (eds): Die naturlichenPflanzenfamilien 2(11). Wilhem Engelmann, Leipzig, Germany, pp. 1-6.

Crum, H. (1972): A taxonomic account of the family Erpodiaceae. - Beih. Nova Hedwigia 23: 201-224.

Daniels, A. E. D., Mabel, J. L. and Daniel, P. (2012): The Erpodiaceae (Bryophyta: Isobryales) of India. - Taiwania 57: 168-171.

Hodgetts, N. G. (1996): British Bryological Society expedition to Mulanje Mountain, Malawi. 3. Erpodiaceae (Musci). - J. Bryol. 19: 113-118. https://doi.org/10.1179/ jbr.1996.19.1.113

Magill, R. E. and van Rooy, J. (1998): Erpodiaceae-Hookeriaceae. - In: Leistner, E. O. (ed.): Flora of Southern Africa, Bryophyta. Part I, Musci 3. Natl. Bot. Inst., Pretoria, South Africa, pp. 445-622.

Mitten, W. (1873): On new species of Musci from Ceylon. - J. Linn. Soc., Bot. 13: 292-330.

Pursell, R. A. (1994): Erpodiaceae. In: Sharp, A. J., Crum, H. A. and Eckel, P. M. (eds): The moss flora of Mexico. 2. Orthotrichales to Polytrichales. - Mem. New York Bot. Gard. 69: 581-588.

Pursell, R. A. and Allen, B. H. (2007): Erpodiaceae. - In: Flora of North America Editorial Committee (ed.): Fl. N. America 27. Oxford Univ. Press, New York, USA, pp. 470-475.

Stone, I. G. (1997): A revision of Erpodiaceae with particular reference to Australian taxa. J. Bryol. 19: 485-502. https://doi.org/10.1179/jbr.1997.19.3.485 